\title{
Qatar Digital Library: A New Phase of Digital Archives
}

\begin{abstract}
Qatar Digital Library is a collaboration project by Qatar Foundation and the British Library to have an open access digital archive which aim to benefit people around the world. QDL offers cultural and historical materials of the Gulf and other regions and make it available online for everyone. The aim of QDL is to improve the understanding of the Islamic world, Arab cultural heritage, and the modern history of the Gulf for the public and the academic researchers.
\end{abstract}

Keywords: Digital; history; archive; Qatar

\section{Digitale Bibliothek in Katar: Eine neue Phase des Digitalen Archivs}

Zusammenfassung: Die Digitale Bibliothek in Katar ist ein gemeinsames Projekt der Qatar Foundation und der British Library. Es bietet das Digitale Archiv Open Access an, damit Menschen aus der ganzen Welt es nutzen können. Die Bibliothek bietet Kulturgüter und historische Materialien der Golf- und anderer Regionen online an. Das Ziel dabei ist die Verbesserung des Wissens über die Arabische Welt, das arabische kulturelle Erbe und die moderne Geschichte der Golf-Region, nicht nur für Wissenschaftler, sondern auch für Interessierte ganz allgemein.

Schlüsselwörter: Digitale Bibliothek; Geschichte; Archiv; Katar

\section{The partnership}

The Qatar Digital Library emerged from a partnership known as the 10-year Memorandum of Understanding between Qatar Foundation (QF), the Qatar National Library (QNL) and the British Library (BL). ${ }^{1}$ The purpose of this partnership was to digitize available historical materials such as documents, photographs, maps, reports, and manuscripts related to the Gulf and Islamic history and make it open to the public in a digital portal. As it first started with material from the British Library this was extended to material owned by Qatar National Library and other institutions. Qatar Digital Library is available free of

\footnotetext{
${ }^{1}$ https://www.qdl.qa/en/about.
} 
Preprints der Zeitschrift BIBLIOTHEK - Forschung und Praxis, 2019, AR 3291 Al-Mutawa

Dies ist ein Preprint $(\mathrm{cc})$ BY-NC-ND. Die endgültige Publikationsfassung erscheint beim Verlag De Gruyter unter https://www.degruyter.com/view/j/bfup

charge, and has managed to gain 5,5 million visitors and 800,000 user sessions resulting in 6 million visits since its establishment. ${ }^{2}$

The partnership for the Qatar Digital Library between the Qatar National Library and the British Library can be divided into three phases that represent a complete first phase, an ongoing second phase and an agreed upon third phase. The contract for the first phase was signed in June 2012 for the 10-year collaborative program, and it officially began in July 2012 lasting to December 2014 for a duration of 30 months. The aim of this phase was to digitize 500,000 images from the Gulf collection in the British Library found in the India Office Records. Gulf Arab music, maps, and Arabic manuscripts on the sciences. On 22 October 2014 QDL portal was launched in both Education City located in Doha, Qatar and the British Library. Within the first day, the webpage had received 8000 page views, compared to the 6,500 British Library reading room requests over the course of 14 years (from 2000-2014). Within the first year, QDL received 325,000 users, 430,000 sessions and 3 million page views. ${ }^{3}$ This shows how the digitization of the historical material can make a huge difference for the public by making the materials available regardless of place and time.

As it started in 2012 with the digitization of a wide range of British library collection content, the website launched in October 2014 contains unknown material to the wider public. By 2015 British Library has refurnished the $5^{\text {th }}$ floor in the BL headquarters and built up the digitization center of the British LibraryQatar Foundation Project to begin Phase 2 (January 2015 to December 2018). Technology such as digitization machines, high-tech photographing equipment and a small preservation conservation lab to support the workflow. In February and May 2015, the British Library obtained additional Dell compellent storage. ${ }^{4}$ This computer storage system helps automate data movement to facilitate data storage in a virtualized manner. Staff was hired to look through the documents of the archive and check their relevance for the project before the conservation lab decides if it could be digitized and in what way the digitization or photography should be done.

There is a different workflow for the Arabic and Islamic manuscripts, which come from both the Qatar Digital Library and the British Library. Much of the digitization process uses Optical Character Recognition, (OCR) a software that converts document text into machine-readable text. Currently, OCR

\footnotetext{
${ }^{2}$ https://www.bl.uk/projects/british-library-qatar-foundation-partnership.

${ }^{3}$ Internal source, QDL.

${ }^{4}$ https://www.bl.uk/aboutus/foi/transparency/contracts/Contract\%200PS9514.pdf.
} 
text is only available for type-written English documents. ${ }^{5}$ In general one can say that the developed workflow in this project is are model workflows for other digitization projects of the British Library and the Qatar National Library.

Copious efforts were placed into the metadata to simplify the searches as it is a bilingual project and the text has to be searchable in English (where most of the text is originally in English) and Arabic. For example, by searching 'Qatar flag in the QDL archive, 23,468 matches in 2,965 records come up ${ }^{6}$ (see Figure 1 below).

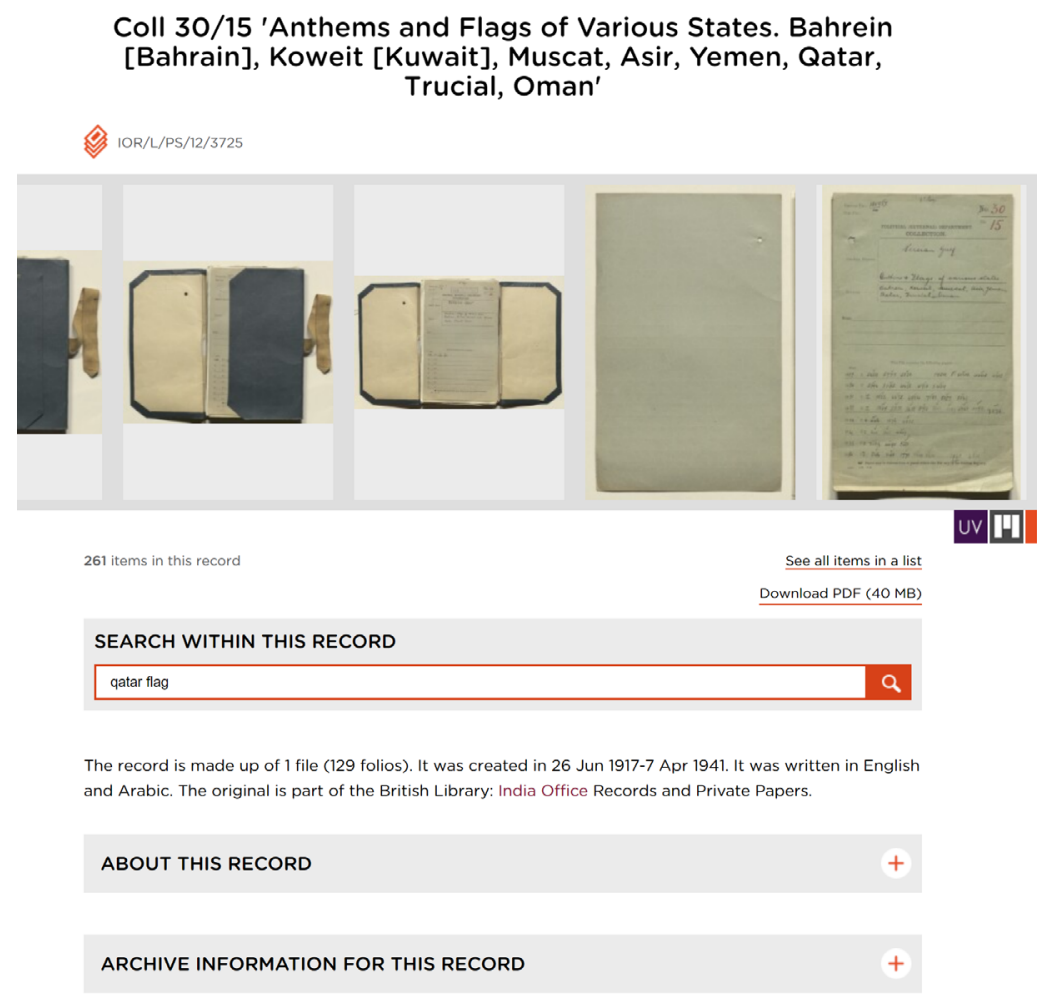

Fig. 1: Coll 30/15 'Anthems and Flags of Various States. Bahrein [Bahrain], Koweit [Kuwait], Muscat, Asir, Yemen, Qatar, Trucial, Oman' Ref: IOR/R/15/2/1694

Qatar Digital Library offers cultural and historical materials of the Gulf and other regions and makes it available online for everyone. The aim of QDL is to improve the understanding of the Islamic world, Arab cultural heritage, and the modern history of the Gulf, among those with a general interest in the Gulf history and the academic researchers.

\footnotetext{
${ }^{5}$ https://www.qdl.qa/en/how-search-archive

${ }^{6}$ The matches were located on the date 27 February, 2019 and is subject to change in the future with the addition of more materials.
} 


\section{The content}

The materials available in the QDL currently are more than 1.3 million pages, with each item accompanied by a description in both Arabic and English, making it a dual-language platform. The QDL collection includes historical records, files, volumes, maps, photographs, and sound recordings related to the Gulf and Qatar, as well as more than 38,000 pages of medieval Arabic manuscripts relating to science, medicine, math, and geometry. The importance of these materials is that most of them are primary sources which have not been catalogued or seen by public, so having them online gives a huge opportunity for researchers to enrich their studies. One example of such new primary sources are the India Office records of the years 1763-1951 where parts concerning the Gulf region are available. These documents have the correspondences of the British government in the Gulf, either between British employees themselves regarding incidents between employees and Gulf rulers, or of documentation records. In both cases the India Office Records allow citizens in the Gulf to have a further understanding of the historical events from a British perspective.

Expert articles on the digitized items were also written during the first phase and are being continually added to the archive in order to provide historical context and makes it easy and more attractive to students and the general public to explore history. The articles are produced by a wide range of experts with different backgrounds and nationalities. This further contextualizes the work and brings in a new world view, as most of the document are inherently Western-centric, being written by the British for the British. However, making these documents globally accessible along with expert articles provides people with the opportunity to revisit history and analyze the documents from their own perspective.

The Qatar Digital Library has around 25,000 medieval Arabic Islamic sciences manuscripts, and the British Library possesses 15,000 Arabic manuscript works in 14,000 volumes. ${ }^{7}$ Manuscript subjects cover medicine, astronomy and astrology, various mathematic subjects, zoology, falconry, chess, mechanics, agriculture, military art and science, Islamic law, geography and more. The earliest dated manuscript is Kitab al-ghadhi wa-al-mughtadhi, created in Dhu al-Qa'dah, Mosul, Iraq in 348 AH/970 CE. Its original manuscript is in the British Library: Oriental Manuscripts. Figure 2 below is a digitized page from the manuscript. $^{8}$

\footnotetext{
${ }^{7}$ https://www.qdl.qa/en/arabic-manuscripts-collection-british-library.
}

${ }^{8}$ https://www.qdl.qa/en/archive/81055/vdc 100022561723.0×000001. 


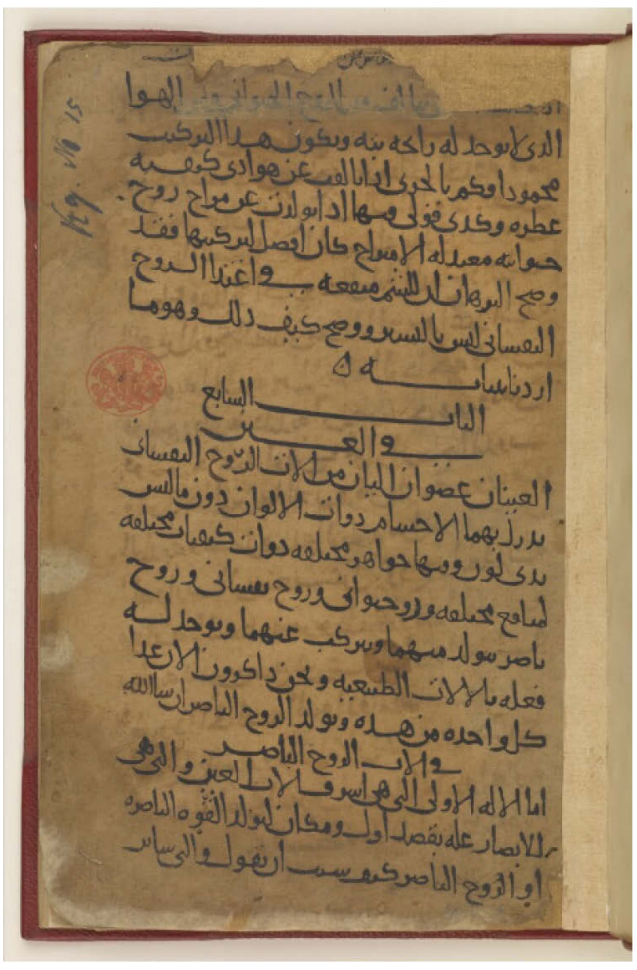

Fig. 2: Kitāb al-ghādhī wa-al-mughtadhī كتاب الغاذي و المغتني lbn Abī al-Ash‘ath, Aḥmad ibn Muḥammad ابن [1r] (12/114) Ref: 2600

This manuscript is a treatise on dietetics and body nourishment, written by Abu Jafar Ahmad ibn Muhammad ibn Abi al-Ash'ath (d. 360/970). The digital collection has missing parts of the original manuscript; this particular copy was made in 348/970 in Mosul, Iraq.

QDL also has an extensive map collection as a result from both libraries. Much effort was put into the first years of digitization to make all the maps available. Most maps dating from 1800 onwards. However there are a few works that date from the 1400s. The 'Sixth Map of Asia', written in Latin, was created in 1478 and is part of the Qatar National Library collection. ${ }^{9}$ It is originally a Latin copy of the Greek work by Ptolemy titled Geographia. It is $26 \times 47 \mathrm{~cm}$.

\footnotetext{
${ }^{9}$ https://www.qdl.qa/en/archive/qnlhc/2702.1.
} 
Preprints der Zeitschrift BIBLIOTHEK - Forschung und Praxis, 2019, AR 3291 Al-Mutawa Dies ist ein Preprint $(\mathrm{cc})$ BY-NC-ND . Die endgültige Publikationsfassung erscheint beim Verlag De Gruyter unter https://www.degruyter.com/view/i/bfup

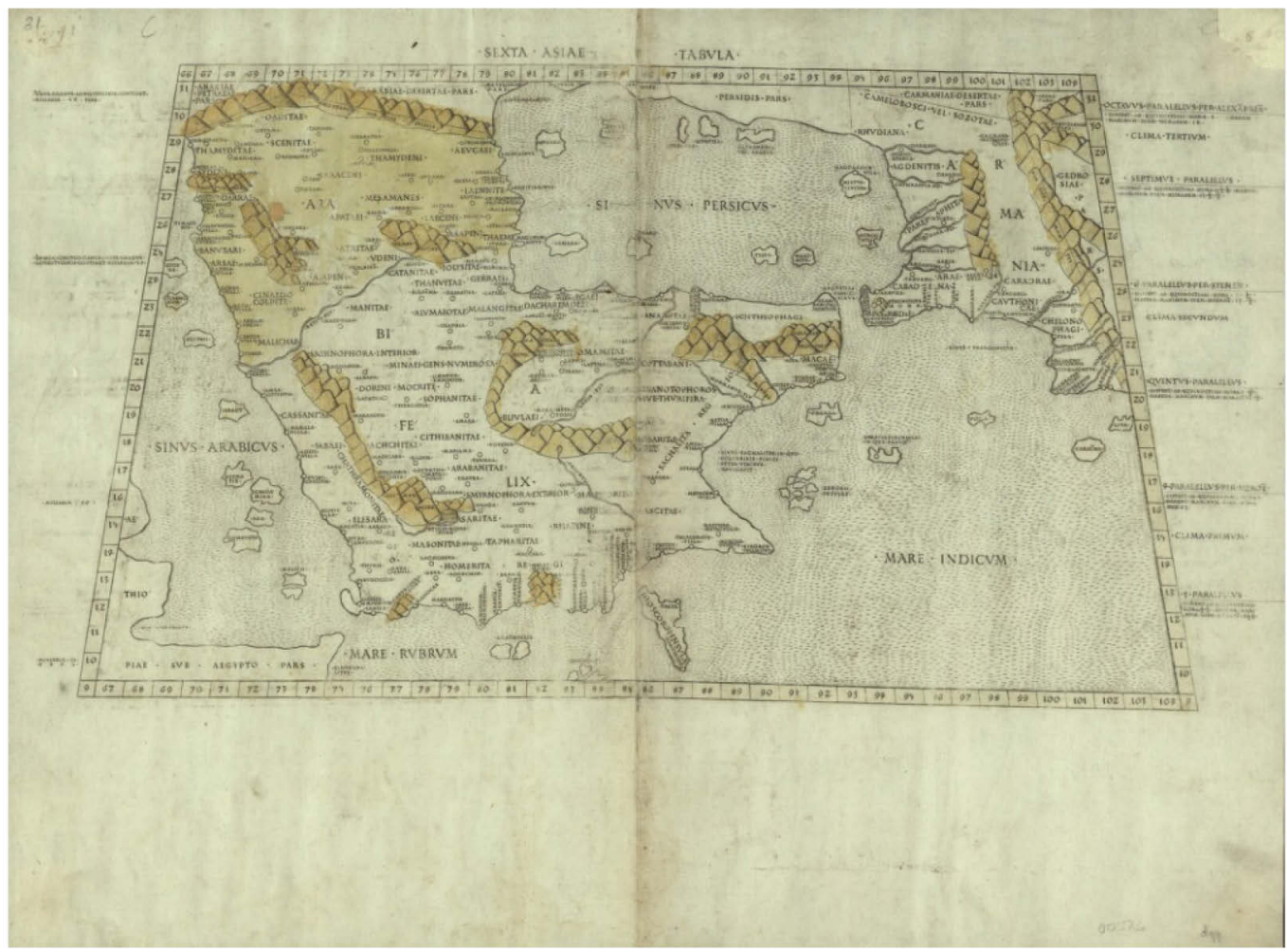

Fig. 3: Sixth Map of Asia [F-1-1] (1/1) Ref: 2702

QDL has also added a timeline filter to its archive search database, and it is a particularly useful feature for narrowing down search results to particular dates with its From: and To: feature. Furthermore, it acts as a visual aid for how many archived items there are across the years. When a user hovers their mouse over the graph, a tool further refines their search by locating how many results are in a specific year. Below in Figure 4, the mouse hovering over the graph reveals there are $109.9 \mathrm{k}$ results stemming from 1925. 
Preprints der Zeitschrift BIBLIOTHEK - Forschung und Praxis, 2019, AR 3291 Al-Mutawa

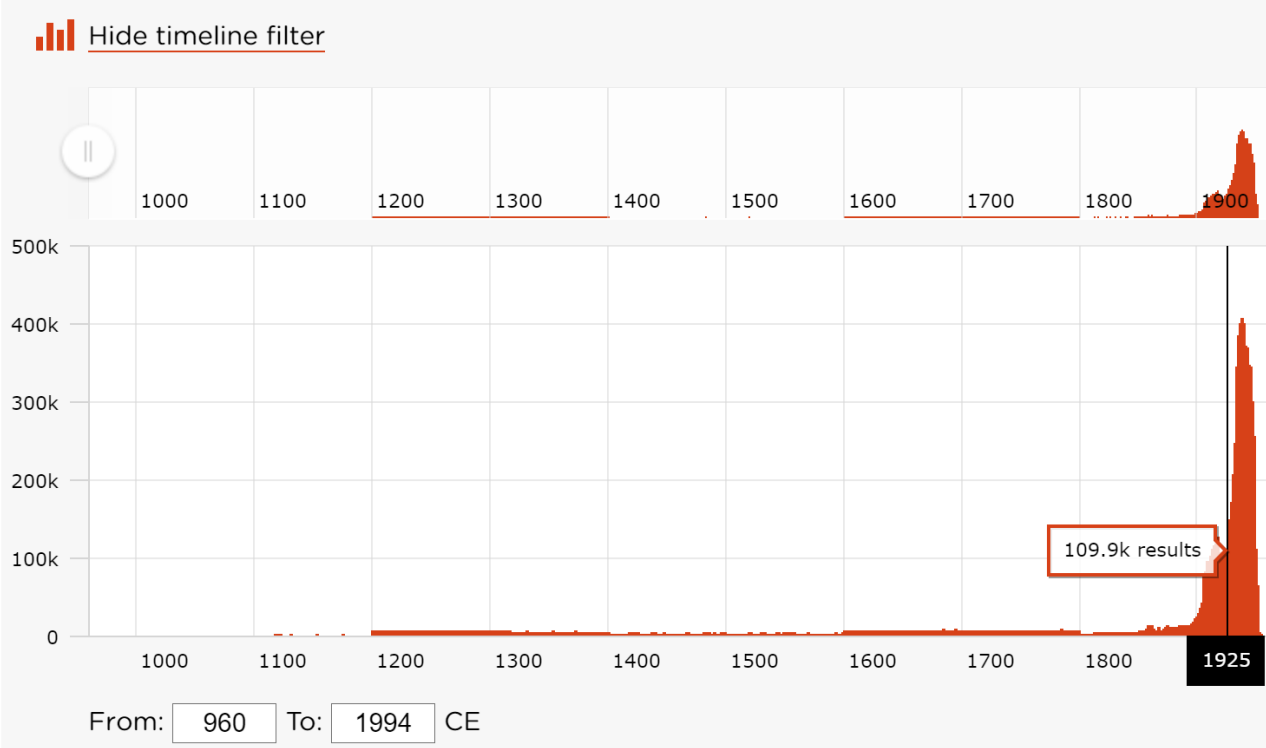

Fig. 4: Timeline feature available in the QDL Archive search

One of the largest components of the QDL-BL partnership is the digitization of the India Office Records. The records contain a vast number of documents ranging from 1600-1858 that were pertinent to the colonial efforts of the British Empire. ${ }^{10}$ The documentation is still not complete, as the documents shelved in the British Library span almost $15 \mathrm{~km}$, and is quite a feat to accomplish. However, recent digitization developments are expanding the scope and completion of this project. Phase 2 of the QDL partnership is expanding upon the archive with an added 970,000 pages of documents, maps and photographs. ${ }^{11}$

\section{The Usage}

The Second Phase as agreed between the two parties (BL \& QNL) has lasted 48 months from January 2015 to December 2018 with an attempt to digitize more than 1 million images from the British Library's vast collection in the India Office records and Arabic manuscripts in the field of sciences. ${ }^{12}$ The second phase witnessed statistics showing over 1 million visits, with the majority of users being from Saudi Arabia, the USA, and Qatar. As proof of sustained usage, statistics showed that January 2015 saw an

\footnotetext{
${ }^{10}$ https://www.qdl.qa/en/india-office-records.

${ }^{11}$ https://qnl.qa/en/about/news/second-phase-qatar-foundation-qatar-national-library-and-british-library-partnership.

12 Internal QDL Source.
} 
average usage of 5.28 pages per session with an average session lasting over 3 minutes, and in January 2018 there was an average usage of 5.23 pages per session with each session lasting over 3 minutes.

Moving to the Third Phase, which was set to begin in January 2019 and conclude in December 2021 with a duration of 36 months, the project intends to digitize 900,000 BL Gulf collection materials including more Arabic music, maps, and manuscripts on science. The different between the third phase and the previous two is that in the first two phases the materials used were already catalogued and available to the public in the British Library since 1979, while the materials that will be digitized in the third phase are uncatalogued and have not seen before by the public. Sound recording of Gulf Arabic music were immensely popular in Phase One, and as such there will be a return of it in Phase Three. ${ }^{13}$ As part of the goal to bridge the past with the future, during the First Phase the British Library began recording music and audio of traditional Gulf music to create a musical database. The sound recordings are available on Soundcloud's Qatar Digital Library page, ${ }^{14}$ and in an effort to make the experience more interactive, it is reported that musical events at Qatar National Library will take place to accompany these sound recordings. Furthermore, due to the popularity of the maps databases in Phase One, they will see a return in Phase 3. There are plans to develop the interactive elements of the maps to engage more interest and make QDL page visits a more engaging experience for users.

The online accessibility of these materials would encourage yet more advanced research and scholarship on Qatar and the Gulf states, and would transform the understanding of the Gulf history. QDL is an ongoing project that will facilitate growth in new and exciting studies of the region's history and heritage. The project is expanding to include archival materials from other partners as well such as the Ottoman state archives, French diplomatic archives, National Archive of the Netherlands, National Archives of India, and the Maharashtra State Archives in Mumbai. Those collections will lead to consider QDL as one of the largest online resources for Arab and Islamic History which is open access for everyone without limitations. However, this new phase presents a series of potential obstacles primarily in the form of technical challenges in integrating the cataloging systems as not all the institutions are following the same metadata schema. In addition, each library uses different transliteration formats which leads to the need to find solutions to avoid any conflict in the names and locations. Furthermore, there is the copyright and open access issue, immense efforts were made by the team to ensure adherence to international standards of copyright and to prevent piracy.

\footnotetext{
13 Internal QDL Source.

${ }^{14}$ https://soundcloud.com/qatar-digital-library.
} 
Preprints der Zeitschrift BIBLIOTHEK - Forschung und Praxis, 2019, AR 3291 Al-Mutawa

Dies ist ein Preprint $(\mathrm{cc})$ EY-NC-ND. Die endgültige Publikationsfassung erscheint beim Verlag De Gruyter unter https://www.degruyter.com/view/i/bfup

The Qatar Digital Library is a worldwide, freely accessible reference resource for everyone, whether those with a public interest in Gulf history or academic researchers conducting innovative and rigorous scientific research. This will lead to a revolutionary development in the digital humanities and digital learning perspective worldwide, and it will result in the production of more literature and research about Qatar and the Gulf.

Maryam Ahmed Al-Mutawa

Qatar National Library

Education City

P.O. Box 5825

Doha

Qatar 